\title{
Morbid Obesity and Motivation for Bariatric Surgery
}

\section{Obesidad Mórbida y Motivación para la Cirugía Bariátrica}

\author{
Edith Gerardina Pompa Guajardo, Cecilia Meza Peña, Walter Daniel García Cantú. \\ Universidad Autónoma de Nuevo León, México \\ (Rec.: agosto de 2017 - Acept.: noviembre de 2017)
}

\begin{abstract}
Morbid obesity is a disease affecting the health of thousands of people around the world, representing a great economic burden for health services. One of the most effective methods of weight reduction is bariatric surgery; however this procedure is commonly used only after other weight reduction methods have failed. This study explores the importance of certain elements as pre- and post-surgery motivators, as well as their relevance in the evolution of the bariatric patient. In this qualitative study we analyzed the discourse of 9 morbid obese people who had gone through bariatric surgery to lose weight, to identify their motivation to do the bariatric procedure, as well as doing and keeping changes to their lifestyle after surgery. We found that the most important motivating factors in pre-surgery period are fear of suffering diseases derived from their morbid obesity, and failure of other weight reduction methods; in postsurgery period, the main motivators to do and keep lifestyle changes are family support and desire to be able to do physical activities. We conclude that motivation should be considered in the treatment of bariatric patients, and treated by a psychologist as part of a multidisciplinary team of health experts.
\end{abstract}

Keywords: Bariatric surgery, discourse analysis, morbid obesity, motivation.

\section{Resumen}

La obesidad mórbida es una enfermedad que afecta la salud de miles de personas en el mundo, y representa una carga económica importante para los servicios de salud. Uno de los principales métodos para reducción de peso es la cirugía bariátrica, sin embargo, este procedimiento comúnmente es usado después del fracaso de otras alternativas. Este estudio explora la importancia de los motivadores en el periodo pre y post-cirugía, así como su relevancia en la evolución del paciente. En este estudio cualitativo se analizaron los discursos de 9 personas con obesidad mórbida que se sometieron a cirugía de reducción de peso, para identificar los motivadores que los llevaron a realizarse la cirugía y para cambiar su estilo de vida tras esta. Los principales motivadores en el periodo pre-cirugía son miedo a sufrir enfermedades derivadas de la obesidad y fracaso de otros métodos de reducción de peso; en el periodo postcirugía, los motivadores para hacer y mantener cambios en el estilo de vida fueron apoyo familiar y deseo de poder hacer actividad física. Concluimos que la motivación debe considerarse en el tratamiento de pacientes bariátricos, y tratada por un psicólogo como parte de un equipo multidisciplinario de expertos en salud.

Palabras clave: análisis de discurso, cirugía bariátrica, motivación, obesidad mórbida.

* Correspondencia: Edith Gerardina Pompa Guajardo. Universidad Autonoma de Nuevo León, Mexico.

Email: edith.pompagj@uanl.edu.mx 


\section{Introduction}

Obesity is a chronic disease of multifactorial origin, characterized by an excessive increase of body fat that puts in risk the health of people suffering from it. Obesity can be related to genetic, environmental or metabolic factors. Because of the complications derived from this chronic disease, it represents an important economic burden for health services around the world, especially in countries where this disease has become epidemic (Moreno, 2013; World Health Organization [WHO], 2012).

In Mexico, there are more than 48 million obese people, representing $71.3 \%$ of population. Following the WHO classification of obesity, this percentage is distributed into $38.9 \%$ overweight people, $32.4 \%$ obese, and $0.1 \%$ of morbidly obese. According to these numbers, there are around 480,000 morbidly obese people in Mexico (Barquera, Campos-Nonato, Hernández-Barrera, Pedroza \& Rivera-Dommarco, 2013).

This disease brings along many physiological complications, such as type two diabetes, cardiovascular, pulmonary and gastrointestinal alterations (Moreno, 2013). Morbid obesity also creates predisposition to psychosocial alterations resulting in low self-esteem, poor body image, anxiety and depression among others (Korbman de Shein, 2010; Marín-Leal, 2015; Moreno, 2013).

One of the most effective methods for weight reduction in morbidly obese patients is bariatric surgery. However, it has been found that most bariatric patients will choose to go through surgery only after other methods of weight reduction have failed, such as diets, exercise, etc. (Lecarós-Bravo, Cruzat-Mandich, Díaz-Castrillón \& Moore, 2015; Van Hout \& Van Heck, 2009).

Factors most commonly associated with successful weight loss before bariatric surgery are: attendance to follow-up monitoring with a surgeon, attendance to support groups, and doing exercise, also having realistic expectations about postsurgery lifestyle changes. Presence of low self-esteem, binge eating and lack of family support, are factors associated with lower weight loss after surgery (Livhits et al., 2010; López-ViIlata \& Soto, 2010; Olguín, Carvajal \& Fuentes, 2014).

To understand the factors leading morbidly obese patients to go through bariatric surgery, it is important to understand the psychological implications behind their motivation. This term refers to those internal states directing an individual's behavior towards specific goals (Larsen \& Buss, 2013). Two types of motivation are distinguished: intrinsic and extrinsic. Intrinsic motivation is associated with activities which are satisfactory by themselves; extrinsic motivation is associated with behaviors motivated by separable results, such as rewards or punishment (Ryan \& Deci, 2000). These forms of motivation are related to the individual's social environment: a supporting environment for the individual's feelings of autonomy and self-competence increases their intrinsic motivation, while a hindering and constraining environment increases extrinsic motivation (Legault, 2016). It is necessary to consider both of these types of motivation when dealing with patients who are candidate for bariatric procedures, since they will direct the patient's actions when doing and keeping changes in their lifestyle (Espantoso de Fitts, Salinas Sedó, Saavedra, Dongo
Valdés, \& Sánchez Vargas, 2014; Tárraga et al., 2014). It has been found (Madeira, do Carmo, Bicha \& Santos, 2017) that self-regulation is positively correlated with higher percentages of weight loss after surgery. This means that bariatric patients will increase their possibilities of losing weight and making changes to their lifestyle, if the motivators in their environment promote their sense of self-competence, autonomy and intrinsic motivation to maintain a healthier lifestyle.

Motivation can be read through the discourse of individuals. Fairclough (1989) states that discourse is a form of representation of the individual's subjective experience of reality though the use of language. An individual discourse is placed within a sociohistorical context thus, besides describing a subject's experience, it also gives information of the way a society perceives phenomena (Tannen, 1995).

The objective of this investigation was to explore, from the analysis of the discourse, the common elements that motivated individuals suffering from morbid obesity to finally decide to go through a bariatric surgery.

\section{Method}

This was a retrospective qualitative study of exploratory character, which describes the experience of formerly morbid obese people (BMI $\geq 40 \mathrm{~kg} / \mathrm{m} 2$ ) who had gone through bariatric procedures. We used a phenomenological perspective, in which phenomena and situations are analyzed based on the way individuals describe their own experience (Trejo, 2010). The phenomenological approach provides a better understanding of the motives that lead people to make informed choices, acting on the ground of their motives and beliefs (PérezSerrano, 1994).

\section{Participants.}

We worked with a sample of nine individuals who fulfilled our selection criteria: having been morbidly obese, having gone through a weight reduction surgical procedure at least one year prior to this research, having lost at least $30 \mathrm{~kg}$ of weight, and having reached a BMI equal to the WHO category of normal weight or overweight ( 25 to $40 \mathrm{~kg} / \mathrm{m} 2$ ). Subjects were selected through the Bariatric Surgery Unit of a local hospital.

\section{Material and procedure.}

We collected data using a semi-structured interview format, through which, according to Adler and Adler (1994), open questions are asked focusing on a given subject, in a way that makes it possible to obtain richer answers, also allowing linking similar subjects. Interviews lasted between 40 and 90 minutes, all of them were recorded in audio and then were transcript.

We first talked to the institution's directives to explain the objective of this research, and to ask for permission to interview some of the patients. We then asked the Unit's staff to inform the patients going to their follow-up sessions if they would be interested in collaborating in this research. We contacted those who agreed, establishing a day to be interviewed.

We asked for the participants' informed consent, in accordance with the ethical aspects in research in humans established 
in the Helsinki Declaration of the World Medical Association (2015) and in the ethical code by the Sociedad Mexicana de Psicología (2010).

\section{Data Analysis.}

All interview transcripts were included in a single meta file, and we used the Atlas.ti software to build units of analysis based on the transcripts. Since this is a qualitative exploratory study, and because of the data collection format, we can notice that this is an inductive study, and therefore, the categories of analysis are not given previously, but emerge from the analysis of the discourse as one confronts the texts (Santander, 2011). This is the way in which the experiences of the participants that answer our question were analyzed and conceptualized according to the categories that emerge from their discourse. In our case, for the present writing, we focus on the speeches of the interviewees who referred to our research question. The number of participants was determinate by the saturation of answers. Finally, we chose fragments from the discourses and compared them with elements from literature.

\section{Results}

The sample was formed by six men and three women, whose average age was 39.1 years $(S D=7.80)$. Five participants were married and four were single, all of them have professional careers and were working at the moment of the interview, with the exception of one who is housewife. Most of the participants reported having a middle-high socioeconomic level. Before surgery, all participants suffered from morbid obesity, with a total average weight of $138.88 \mathrm{~kg}(S D=17.57)$. This value decreased after surgery to an average of $81.44 \mathrm{~kg}(\mathrm{SD}=15.19)$. See Table 1.

Table 1. Socio-demographic characteristics of the patients before and after surgery

\begin{tabular}{|c|c|c|c|c|c|c|c|}
\hline No. & Gender & Age & Occupation & Marital Status & SES & Weight (BS) & Weight (AS) \\
\hline 1 & $M$ & 38 & Doctor & Married & Mid-high & 139 & 107 \\
\hline 2 & M & 47 & Engineer & Married & Mid-high & 125 & 92 \\
\hline 3 & $M$ & 40 & Engineer & Single & Mid-high & 180 & 90 \\
\hline 4 & $\mathrm{~F}$ & 50 & Teacher & Married & Mid-high & 135 & 84 \\
\hline 5 & M & 39 & HR Manager & Single & High & 146 & 91 \\
\hline 6 & $\mathrm{~F}$ & 40 & Housewife & Married & Mid-high & 140 & 75 \\
\hline 7 & $\mathrm{~F}$ & 22 & Student & Single & High & 128 & 61 \\
\hline 8 & M & 40 & Technician & Married & Middle & 132 & 68 \\
\hline 9 & $M$ & 36 & Executive & Single & High & 120 & 65 \\
\hline
\end{tabular}

Notes: $\mathrm{M}=$ male; $\mathrm{F}=$ female; SES = Socioeconomic Status, weight in kilograms; $B S=$ Before surgery; $A S=A f t e r$ surgery.

Two categories of analysis were defined from the participants' discourses: 1) Motivators before surgery, and 2) Motivators after surgery.

\section{Motivators before surgery.}

This category includes the motivating factors that led the participants to go through bariatric surgery. The principal motivating factors before surgery detected in the discourse of participants, were in relation to diseases derived from their excess weight, fear of suffering further health complications, fear of dying, presence of family members with similar weight and health issues, and failure of previous weight reduction methods. There were also psychosocial factors like anxiety, sadness, depression and discrimination, as well as support from other people.
Several participants (six out of nine) reported having a relative with some degree of obesity as well as diseases related with it, such as diabetes, hypertension, and cardiovascular diseases as expressed in the next discourse fragments:

[S1]: I did the surgery because I am diabetic and had many health problems (...) I had high sugar levels [in blood], I needed insulin shots (...) high blood pressure, cholesterol, triglycerides (...) [I told to myself] "I have to do something else or I'll die. (...) I had already done diet, I had lost $30 \mathrm{~kg}$, but I gained them again.

[S3] I already had blood pressure issues (...) [I felt] too tired to walk, to talk (...) I was carrying too much weight, really so much ...it was dangerous, I was a time bomb (...) My biggest fear was that I could develop diabetes. 
[S4] I had the surgery because my levels of blood sugar were too high (...) when the doctor told me I had high sugar levels

I got scared and told to myself "I don't want to be sick, I don't want to be sick" (...) and also my knees started to hurt. All the interviewees also talked about having used other methods of weight reduction before opting for bariatric surgery, such as diets, exercise routines, many kinds of pills, magnet therapy, etc. The lack of satisfactory results with these methods seems to be a further motivator for the search for bariatric surgery:

[S7] Everything started when I was 7 years old, I went to, not kidding, but I've been to like 50 nutritionists, I've met all [from the city where the research was done], I mean, I did everything, and nothing worked.

[S8] I tried doing exercise, diet, pills, and I did lose some weight, but not enough to feel good with myself. I mean... I lost $10 \mathrm{~kg}$ and then gained them again... even if I took the pills, to the exercise routine or the diet, I could not get the results I wanted.

\section{Motivators after surgery.}

This category includes factors which motivated the participants to do and keep lifestyle changes post-surgery. Here we include elements such as: family support, concerns about health, and presence of goals to reach that were formerly impossible due to their excessive weight.

All of the subjects expressed having received support after surgery from family members, especially those who were married with children, as well as from parents and friends:

[S1]: My wife and kids were always there, my parents, too. (...) [S2]: I had the support mostly of my family, they were always with me in every step of the way, and I did it because I knew I had to take care of myself to be able to spend more time with them.

All the participants reported having changed their eating habits, specifically the amount of food they eat, as well as increasing their physical activity. Most of the interviewees expressed goals to exercising more, something that they could not do before the surgery. Losing weight also gave all participants higher self-esteem and positive feelings about themselves.

[S1]: I'm not following a rigorous diet but I'm doing a lot more exercise, and every time I can do more and last longer (...) my heart condition changed drastically, I can run now, I can play more with my children and do other things, like playing soccer.

(...) I wish to run a marathon, if I was fat I wouldn't do it.

[S2]: My eating habits changed drastically. For six months I couldn't eat any solid food, I felt desperate because I used to eat a lot of food (...) I do exercise now, I never felt like doing it before, but I'll do anything to be healthy. (...)

[S5]: I can't eat many things, like dried chicken breast, tortilla, I can't drink soda either (...). Food lasts me longer on the plate, it's not the same anymore, my stomach is smaller so I can't eat the same amount. I do feel hungry every four hours or so, but I eat just a little.
[S6]: I started walking, and then jogging, and now I've run $5 \mathrm{~km}$ already, and I'm preparing to run a $10 \mathrm{~km}$ marathon. (...) I'd like to buy a new house. Or maybe meeting someone and getting married again. (...) I started to see changes a month after surgery, the emotional aspect does feel a lot better. My health improved a lot, I now feel better emotionally and psychologically. I even got a divorce. I got stronger, that's what happened.

[S7]: The main change for me was doing exercise, something I didn't use to do. Now I eat healthy food, obviously I won't eat a hamburger, tacos or drink soda, because now I know what I should and shouldn't eat.

\section{Discussion}

Discourses show that the main factors motivating the interviewed individuals to go through weight reduction bariatric surgery were related to diseases associated with this condition as well as the fear of the possible negative consequences of it, including death. This is congruent with the results found by Karmali, Kadikoy, Brandt and Sherman (2009), Engström, Wiklund, Fagevik, Lönroth and Forsberg (2011), Dongo-Valdés (2012) and Lecarós-Bravo et al. (2015), who agree that one of the most important motivating factors in bariatric patients is a concern about their own integrity and wellbeing, which implies a desire to avoid diseases related to their excess of body weight.

Other important motivating factor was the failure of alternative weight reduction methods. Interviewees reported having used a wide range of methods without success. These results agree with those of Ríos et al. (2010), Maluenda (2012) and Olguín et al. (2014), who reported that a lack of concrete results with treatments similar to those found in this research is also an important motivator for the individual to consider the possibility of going through a bariatric procedure.

The support of family members and friends is important for the proper post-surgery evolution of the patient, since it is common that lifestyle changes for the patient are also adopted by their family (Guisado-Macías, Álvarez Ormazábal, BajoCabello \& Escudero, 2015; Lecarós-Bravo et al., 2015; Ríos et al., 2010). This situation helps to alleviate the stress felt by the individual, thus creating an optimal environment for positive change (Ortiz-Torres, 2013). Concern from family members and friends was found in most of the individuals' discourses. This is also important because a supporting environment is ideal for the increase of intrinsic motivation (Legault, 2016).

Discourses also showed that pre-surgery motivation was mostly extrinsic, while post-surgery motivation was intrinsic. Before the procedure, individuals were found to be motivated mostly because of health issues as well as emotional and social factors, such as medical complications, anxiety and discrimination, as well as a desire to do activities that they were unable to do because of their weight. On the other hand, postsurgery environmental factors were optimal for a change of focus, leading to intrinsic motivation being predominant, which can be appreciated in the patients' enjoyment of being able to pass time with their family in activities in which they couldn't participate prior to the surgical procedure. Perceiving positive changes in their lifestyle also helped them to keep up with the recommendation made by the surgery team. This agrees 
with the model of motivation by Ryan and Deci (2000), which holds that an important factor in intrinsic motivation is a sense of autonomy, something that is perceived in the analyzed discourses, in which individuals express having recovered their bodily movement and with it a sense of self-sufficiency.

One of the main post-surgery supporting elements for the bariatric patient is family and friends. It has been found that if there is no proper post-surgery follow-up, patients can relapse into behaviors leading to recovering the lost weight, and also to the emergence of psychopathologies that can endanger their lives (Olguín et al., 2014; Peterhänser, Petroff, Klinitzke, Kersting \& Wagner, 2014). For this reason, we recommend that bariatric patients should be monitored not only by a surgeon, but by a multidisciplinary team of health experts which should include a psychologist, nutritionist, general doctor, among others (Delgado et al., 2015; Olguín et al., 2014).

Obesity is not only a matter of weight reduction, and it is important to take care of the psychosocial, behavioral and affective dimensions of the person. Acting otherwise could lead to the patient being unable to do and/or keep the lifestyle changes necessary for their recovery. This could happen if the patient's environment does not promote their sense of autonomy and self-sufficiency, and thus their intrinsic motivation (Tárraga et al., 2014). Psychological therapy has positive effects on the patient's motivation to adhere to their new eating and exercise habits (López-Villalta \& Soto, 2010). Thus, by re-signifying and re-learning behaviors, subjects can change their motivation focus from extrinsic ("I keep my weight to avoid being sick"), to intrinsic ("I keep my weight because it's good for me"). Psychological support can also help the patient to keep realistic expectations about the surgery outcomes, as unrealistic expectations about surgery and lifestyle changes can also lead to negative results (Olguín et al., 2014). It's worth mentioning, that of the 9 persons interviewed in this report, only one received psychological support, and by his own initiative.

The compromising of health due to obesity and the failure of alternative methods for losing weight seem to be crucial elements in a patient's choice to opt for bariatric surgery. Work with a multidisciplinary team of health professionals is necessary, as a multifaceted perspective is needed to help patients to adapt to a new post-surgery lifestyle. This includes the need for the patient to be kept properly motivated to adhere to treatments and to make changes in their eating and exercise habits.

The role of the psychologist in the morbidly obese patient's follow-up is related to their understanding of their emotional states, especially those connected to anxiety and depression (Taube-Schiff, Van Exan, Tanaka, Wnuk, Hawa \& Sockalingam, 2015), adaptations of their body image in relation to their new body schema (Marín-Leal, Cortés-Mellado, Díaz-Castrillón \& Cruzat-Mandich, 2017), and to avoid recidivism of behaviors such as binge eating (Shakory, Van Exan, Mills, Keating \& Taube-Schiff, 2015).

Some limitations of the present study are in the chosen method of investigation and the characteristics of the sample. We recommend that future studies include the use of mixed methods enabling a deeper understanding of the subject's own experience. Likewise, we recommend access to a representative or bigger sample which can allow a wider understanding of morbid obese persons going through bariatric procedures.

\section{References}

Adler, P. \& Adler, P. (1994). Observational Techniques. En N. Denzin \& Y. Lincoln (Eds.), Handbook of Qualitative Research (pp. 377-392). California: Sage Publications.

Barquera, S., Campos-Nonato, I., Hernández-Barrera, L., Pedroza, A. \& Rivera-Dommarco, J. (2013). Prevalencia de obesidad en adultos mexicanos, 2000-2012. Salud Pública de México, 55(2), 151-160. Recuperado de http://www.scielo.org.mx/scielo.php?script=sci_ arttext\&pid=S0036-36342013000800012

Delgado, P., Cofré, A., Alarcón, M., Osorio, A., Caamaño, F. \& Jerez, D. (2015). Evaluación de un programa integral de cuatro meses de duración sobre las condiciones preoperatorias de pacientes obesos candidatos a cirugía bariátrica. Nutrición Hospitalaria, 32(3), 1022-1027. doi:10.3305/nh.2015.32.3.9350

Engström, M., Wiklund, M., Fagevik, M., Lönroth, H. \& Forsberg, A. (2011). The meaning of awaiting bariatric surgery due to morbid obesity. The Open Nursing Journal, 5, 1-8. doi:10.2174/1874434601105010001

Espantoso de Fitts, M., Salinas Sedó, G., Saavedra, L., Dongo Valdés, P. \& Sánchez Vargas, V. (2014). Efectividad en la pérdida de peso tras la cirugía de manga gástrica en el Perú. Paper presented at the 6th International Congress on Bariatric and Metabolic Surgery, Madrid, Spain. Abstract retrieved from https://www.bmi-journal.com/index.php/bmi/article/view/201/pdf

Fairclough, N. (1989). Language and power. London: Longman.

Guisado-Macías, J., Álvarez-Ormazábal, J., Bajo-Cabello, B. \& Escudero, A. (2015). Cirugía bariátrica y satisfacción familiar en obesidad mórbida. Bariátrica \& Metabólica Ibero-Americana, 5, 631-640. Recuperado de https://www.bmi-journal.com/index.php/ bmi/article/view/188

Karmali, S., Kadikoy, H., Brandt, M. \& Sherman, V. (2009). What is my goal? Expected weight loss and comorbidity outcomes among bariatric surgery patients. Obesity Surgery, 21(5), 595-603. doi:10.1007/s11695009-0060-z

Korbman-de Shein, R. (2010). Obesidad en adultos: aspectos médicos, sociales y psicológicos. Anales Médicos, 55(3), 142-146. Recuperado de http://www.medigraphic.com/pdfs/abc/bc-2010/bc103f.pdf

Larsen, R. \& Buss, D. (2013). Personality Psychology: Domains of Knowledge About Human Nature. Boston: McGraw-Hill Higher Education.

Lecarós-Bravo, J., Cruzat-Mandich, C., Díaz-Castrillón, F. \& Moore, C. (2015). Significados y vivencias en pacientes adultos sometidos a cirugía bariátrica. Revista Chilena de Neuro-Psiquiatría, 53(2), 77-85. doi:10.4067/S0717-92272015000200002 
Legault, L. (2016). Intrinsic and Extrinsic Motivation. In: V. Zeigler-Hill, T. Shackelford (Eds.), Encyclopedia of Personality and Individual Differences (pp. 1-4). doi:10.1007/978-3-319-28099-8_1139-1

Livhits, M., Mercado, C., Yermilov, I., Parikh, J., Dutson, E., Mehran, A., ... \& Maggard, M. (2010). Behavioral factors associated with successful weight loss after gastric bypass. The American Surgeon, 76(10), 1139-1142. Recuperado de https://www.ncbi.nlm. nih.gov/pubmed/21105629

López-Villalta, M. \& Soto, A. (2010). Actualización en obesidad. Cadernos de Atención Primaria, 17, 101-107. Recuperado de http://www.1aria.com/docs/sections/cardiovascular/obesidad/Actualizaci\%C3\%B3n\%20 en\%200besidad.pdf

Madeira, T., do Carmo, I., Bicha, H. \& Santos, O. (2017). Self-Regulation of Weight After Sleeve Gastrectomy. Behavior Modification. doi:10.1177/0145445517724540

Maluenda, F. (2012). Cirugía bariátrica. Revista Médica Clínica Las Condes, 23(2), 180-188. doi:10.1016/S07168640(12)70296-1

Marín-Leal, L. (2015). Satisfacción con la imagen corporal post cirugía bariátrica en pacientes con obesidad leve (Tesis de maestría, Universidad de Chile, Santiago de Chile). Recuperado de http://repositorio.uchile. $\mathrm{cl} / \mathrm{handle} / 2250 / 136636$

Marín-Leal, L., Cortéz-Mellado, S., Díaz-Castrillón, F. \& CruzatMandich, C. (2017). Body image of women with type I obesity after 2-5 years of subtotal gastrectomy vertical. Revista Mexicana de Trastornos Alimentarios, 8(2), 151-160. doi:10.1016/j.rmta.2017.04.002

Moreno, M. (2013). Definición y clasificación de la obesidad. Revista Médica Clínica Las Condes, 23(2), 124-128. doi:10.1016/S0716-8640(12)70288-2

Olguín, P., Carvajal, D. \& Fuentes, M. (2014). Patología psiquiátrica y cirugía bariátrica. Revista Chilena de Cirugía, 67(4), 441-447. doi:10.4067/S071840262015000400016

Ortiz-Torres, E. (2013). Cambios en las relaciones familiares tras la cirugía bariátrica desde la perspectiva del paciente (Tesis, Universidad de las Américas, Quito). Recuperado de http://dspace.udla.edu.ec/ handle/33000/1753

Pérez-Serrano, G. (1994).Investigación cualitativa l: retos e interrogantes. Madrid, España: La Muralla

Peterhänser, C., Petroff, D., Klinitzke, G., Kersting, A. \& Wagner, B. (2014). Risk of completed suicide after bariatric surgery: a systematic review. Obesity Review, 14(5), 369-382. doi:10.1111/obr.12014

Ríos, B., Sánchez, M., Guerrero, M., Pérez, D., Gutiérrez, S., Rico, M., ... \& Villalobos, E. (2010). El rol del psicólogo en la cirugía bariátrica. Cirujano General,
32(2), 114-120. Recuperado de http://www.medigraphic.com/pdfs/cirgen/cg-2010/cg102i.pdf

Ryan, R. \& Deci, E. (2000). Intrinsic and extrinsic motivations: classic definitions and new directions. Contemporary Educational Psychology, 25, 64-67. doi:10.1006/ ceps.1999.1020

Santander, P. (2011). Por qué y cómo hacer Análisis de Discurso. Cinta Moebio, 41, 207-224. Recuperado de http://www.facso.uchile.cl/publicaciones/ moebio/41/santander.pdf

Shakory, S., Van Exan, J., Mills, J., Sockalingam, S., Keating, L. \& Taube-Schiff, M. (2015). Binge eating in bariatric surgery candidates: the role of attachment and emotion regulation. Appetite, 91, 69-75. doi:10.1016/j.appet.2015.03.026

Sociedad Mexicana de Psicología. (2010). Código ético del psicólogo. México: Trillas.

Tannen, D. (1995). The power of talk: Who gets heard and why. Harvard Business Review, 73(5), 138-149. Recuperado de https://hbr.org/1995/09/the-power-oftalk-who-gets-heard-and-why

Tárraga, M., Rosich, N., Panisello, J., Gálvez, A., Serrano, J., Rodríguez-Montes, J. \& Tárraga, P. (2014). Eficacia de las estrategias de motivación en el tratamiento del sobrepeso y obesidad. Nutrición Hospitalaria, 30(4), 741-748. doi:10.3305/nh.2014.30.4.7704

Taube-Schiff, M., Van Exan, J., Tanaka, R., Wnuk, S., Hawa, R. \& Sockalingam, S. (2015). Attachment style and emotional eating in bariatric surgery candidates: The mediating role of difficulties in emotion regulation. Eating Behaviors, 18, 36-40. doi:10.1016/j. eatbeh.2015.03.011

Trejo, F. (2010). Fenomenología como método de investigación: una opción para el profesional de enfermería. Enfermería Neurológica, 11(2), 98-101. Recuperado de http://www.medigraphic.com/pdfs/enfneu/ ene-2012/ene122h.pdf

Van Hout, G. \& Van Heck, G. (2009). Bariatric psychology: psychological aspects of weight loss surgery. Obesity Facts, 2,10-15. doi:10.1159/000193564

World Health Organization. (2012). Obesity and overweight. Recuperado de http://www.who.int/mediacentre/ factsheets/fs311/en/

World Medical Association. (2015). Helsinki Declaration: ethical principles for medical research involving human subjects. Recuperado de http://www.wma.net/ es/30publications/10policies/b3 